\begin{abstract}
Iranica
Abstracta Iranica Revue bibliographique pour le domaine irano-aryen

Volume 32-33 | 2013

Comptes rendus des publications de 2009-2010
\end{abstract}

\title{
André Lemaire. Un nouveau type d'inscription phénicienne
}

Astrid Nunn

\section{OpenEdition}

1 Journals

Édition électronique

URL : http://journals.openedition.org/abstractairanica/40354

DOI : 10.4000/abstractairanica.40354

ISSN : 1961-960X

\section{Éditeur :}

CNRS (UMR 7528 Mondes iraniens et indiens), Éditions de l'IFRI

\section{Édition imprimée}

Date de publication : 1 décembre 2013

ISSN : 0240-8910

\section{Référence électronique}

Astrid Nunn, « André Lemaire. Un nouveau type d'inscription phénicienne », Abstracta Iranica [En ligne], Volume 32-33 | 2013, document 92, mis en ligne le 01 juillet 2016, consulté le 29 septembre 2020. URL : http://journals.openedition.org/abstractairanica/40354; DOI : https://doi.org/10.4000/ abstractairanica. 40354

Ce document a été généré automatiquement le 29 septembre 2020.

Tous droits réservés 


\title{
André Lemaire. Un nouveau type d'inscription phénicienne
}

\author{
Astrid Nunn
}

\section{RÉFÉRENCE}

André Lemaire. « Un nouveau type d'inscription phénicienne ». Trans. 37, 2009, p. 89-97.

1 Il s'agit de cinq inscriptions parues dans le dernier volume de R. Stucky sur le temple d'Eshmun de Sidon (Antike Kunst, Beiheft 19, Bâle 2005, (cf. Abs. Ir.29, 2006, nº 91) et que l'A. reprend en détail. Ces palindromes, souvent appelés «carrés magiques » et qui ont été mis au jour il y un peu plus d'un siècle, n'avaient pas encore suffisamment attiré l'attention. Les deux inscriptions les mieux conservées ont été gravées de part et d'autre d'une dalle de marbre. On peut les dater entre 400-350 av. J.-C. L'influence grecque ne se retrouve que dans la lecture en boustrophédon. Les noms lisibles sont ceux de 'ŠTRT (Ashtarte) et de ŠMŠ'R (Shamash et 'R qui est un appellatif divin). Les autres lignes sont conjecturales et comprennent vraisemblablement des noms et des attributs divins. Mieux que de « carrés magiques », il s'agit de jeux intellectuels.

\section{AUTEURS}

\section{ASTRID NUNN}

Université de Munich 